\title{
Non-specifically labelled cells that simulate bone marrow metastases in patients with non-metastatic breast cancer
}

M Lagrange, J M Ferrero, J L Lagrange, J C Machiavello, J Monticelli, C Bayle, A Creisson, M Namer, A Thyss, C Bourcier, J Gioanni, M Schneider

\begin{abstract}
Aims-To determine whether the presence of disseminated bone marrow tumour cells at diagnosis is a prognostic factor for breast cancer patients at high risk of recurrence or bone metastasis, and to assess their presence as a criterion for evaluation of the potential benefits of adjuvant chemotherapy.
\end{abstract}

Methods-Multiple bone marrow aspirates from 72 breast cancer patients free from metastasis were obtained during surgery at the time of diagnosis and were tested immunologically by alkaline phosphatase antialkaline phosphatase technique with a panel of three antiepithelial monoclonal antibodies (MoAb) $\mathbf{K L}_{1}$, EMA, and $\mathrm{HMFG}_{2}$.

Results-In nine of 72 patients, with each $\mathrm{MoAb}$ tested, numerous strongly positive cells always isolated were observed. However, it was demonstrated that these cells were non-specifically labelled and could be found in normal controls.

Conclusions-There was no evidence of marrow tumour cells in 72 operable breast cancer patients. It is suggested that published results may be greatly overestimated and that non-specific labelling may be undetected. More specific MoAb should be found and a correlation with molecular biology should be performed if this criterion is to be considered as a prognostic factor.

(f Clin Pathol 1997;50:206-211)

Keywords: bone marrow tumour cells; breast cancer; immunocytochemistry.

Numerous studies suggest that breast cancer metastasises at a very early stage. Although the prognosis for breast cancer patients without metastases (MO) at the time of initial disease staging (including isotopic scanning and biochemical tests) remains unknown, almost $50 \%$ of patients relapse within five years, ${ }^{1}$ and $25 \%$ of those who are node-negative at initial diagnosis relapse within 10 years. $^{2}$ The skeleton and bone marrow are often the first sites of metastasis in breast cancer patients, ${ }^{13}$ yet risk assessment using conventional prognostic factors (number of involved nodes, tumour size, peritumoral vascular invasion, hormone receptor status) is disappointing. ${ }^{145}$
Sloane et al were the first to demonstrate successfully marrow tumour cells in breast cancer patients with metastases using an immunocytochemical technique, whereas malignant cells were not found in haematoxylin/ eosin sections. ${ }^{6}$ Since then, more than 25 publications on the subject have concluded that occult bone marrow micrometastases are present at the time of earliest detection of nonmetastatic breast carcinoma. The main studies concerning marrow samples from $\mathrm{M} 0$ patients during surgery are listed in table 1 . Results are most diverse with respect to detection rate (mean $19 \%$, range $0 \%-44 \%$ ) and prognostic relevance. Some investigators have reported a correlation with conventional prognostic factors such as tumour size, lymph node status, and intratumoral vascular invasion, ${ }^{13}$ whereas others have failed to observe such relationships. ${ }^{578}$ The presence of marrow tumour cells is generally considered an essential prognostic factor for early recurrence, ${ }^{137}$ and relapse-free survival. ${ }^{358}$ Marrow tumour cells are also reportedly a strong independent prognostic factor for bone metastasis, ${ }^{19}$ and overall survival. ${ }^{10}$ Moreover, marrow tumour cell detection has thus been proposed as a replacement for axillary lymphadenectomy in cancer patients with clinically free axillary lymph nodes. ${ }^{10}$ However, several authors failed to find any positive cases ${ }^{24} 6$ while two others found only a low rate of positivity (table 1$).^{11}{ }^{12}$ This considerable variability in results is probably due to the various criteria used for identification of marrow tumour cells and the numerous differences in methodology. Studies differ not only by the immunological technique used, but also the number and type of antibodies, and whether controls are used to guarantee accurate interpretation (table 1). The feasibility of the technique is another decisive factor, because results may be used to select candidates, and in particular node-negative patients, for adjuvant therapy. ${ }^{5}$

In the present study, bone marrow aspirates from breast cancer patients free from metastases at time of initial diagnosis were studied immunocytologically with all known guarantees concerning methodology according to literature results: analysis of multiple bone marrow aspirates, ${ }^{1513}$ use of alkaline phosphatase antialkaline phosphatase (APAAP) immunocytochemical technique ${ }^{14}$ on cytospins which allows much better identification of labelled cells than immunofluorescence, ${ }^{15}$ and 
Table 1 Techniques used and results of major publications about the research of marrow tumour cells in patients without metastases at the time of primary surgery

\begin{tabular}{|c|c|c|c|c|c|c|}
\hline \multirow[b]{2}{*}{ Authors } & \multirow[b]{2}{*}{ Specimens } & \multirow[b]{2}{*}{ Immunological technique } & \multirow{2}{*}{$\begin{array}{l}\text { Negative } \\
\text { control without } \\
\text { primary } \\
\text { antibody }\end{array}$} & \multirow[b]{2}{*}{ Antibodies } & \multicolumn{2}{|c|}{ Positive patients } \\
\hline & & & & & Number & $\%$ \\
\hline Sloane $^{6}$ & BMA, Ficoll, inclusion & Alkaline phosphatase & Yes & Polyclonal EMA & $0 / 28$ & 0 \\
\hline Cote $^{7}$ & BMA, Ficoll, smears & Immunofluorescence & Not specified & Monoclonal C26* $\mathrm{T} 16^{\star} / \mathrm{AE} 1^{\star}$ & $18 / 51$ & 35 \\
\hline Porro $^{22}$ & Cell suspension from BMB & Immunofluorescence & Not specified & Monoclonal MBRI* & $25 / 159$ & 16 \\
\hline Ellis ${ }^{23}$ & BMA, Ficoll, drop air dried & Indirect immunoglucose oxidase & Yes & Monoclonal $35 \mathrm{bH} 11 \dagger, 34 \mathrm{bE} 12 \dagger$ & $2 / 9$ & 22 \\
\hline Giai $^{12}$ & $\mathrm{BMA}$, inclusion & Immunoperoxidase & Yes & Monoclonal $\mathrm{AB} / 3^{\star}$ & $1 / 39$ & 2.6 \\
\hline Mathieu $^{2}$ & BMB & Peroxidase-antiperoxidase & Yes & KL1 & $0 / 48$ & 0 \\
\hline Courtemanche ${ }^{11}$ & BMB & Avidin-Biotin peroxidase & Not specified & Monoclonal LICR-LON M8* & $1 / 50$ & 2 \\
\hline Mansi ${ }^{3}$ & BMA, Ficoll, smears & Alkaline phosphatase & Yes & Polyclonal EMA & $89 / 350$ & 25 \\
\hline Diel $^{1}$ & BMA, Ficoll, smears & Streptavidin alkaline phosphatase & Not specified & Monoclonal $2 \mathrm{E} 11 \ddagger$ (anti-TAG 12 protein) & $114 / 260$ & 44 \\
\hline Osborne $^{8}$ & BMA, Ficoll, smears & Immunofluorescence & Not specified & Monoclonal C26*, T16*, AE $1 \dagger$ & $111 / 348$ & 32 \\
\hline Pecorini ${ }^{4}$ & $\mathrm{BMB}$ & APAAP & Yes & $M 772 \dagger, M 821 \dagger, M 717 \dagger$ & $0 / 20$ & 0 \\
\hline Harbeck $^{5}$ & BMA, Ficoll, smears & APAAP & Not specified & $\begin{array}{l}\text { Monoclonal EMA, EMA } \\
\text { CK, } 12-\mathrm{H} 12 \ddagger \text { (anti-TAG } 12 \text { protein) }\end{array}$ & $38 / 100$ & 38 \\
\hline Menard $^{24}$ & BMA, Ficoll, cytospin & APAAP & Not specified & $\begin{array}{l}\text { Monoclonal MBRI } \star / M B R 8 \star / M O V 8^{\star} / \\
\text { MOV16 }^{\star} / \mathrm{MLUCI}^{\star}, \mathrm{CK} 2\end{array}$ & $62 / 197$ & 31 \\
\hline
\end{tabular}

$\mathrm{BMB}=$ bone marrow biopsy; $\mathrm{BMA}=$ bone marrow aspirate; $\mathrm{APAAP}=$ alkaline phosphatase antialkaline phosphatase; $\mathrm{CK}=$ cytokeratin.

$\star$ Antiepithelial membrane antigen; †Anti-ck; $\ddagger$ Antipolymorphic epithelial mucin.

avoids interference of endogenous enzymes much better than the peroxidase technique. Moreover, we tested a panel of four antiepithelial monoclonal antibodies (MoAb), none of which is specific when used alone. ${ }^{5}$ Study of the sensitivity of the method, assessment of its feasibility using known tumoral epithelial cells and marrow samples from carcinoma free controls, negative control of the reaction by replacement of each primary antibody by its isotype identical IgG, were performed. Finally, systematic comparison of cytospins stained with May-Grünwald-Giemsa (MGG) and immunologically treated cytospins, using a meticulous morphological study in case of immunocytochemical positivity was performed.

\section{Materials and methods}

PATIENTS

Between February 1993 and July 1994 six marrow aspirates were obtained during surgery for a primary breast tumour from 72 unselected, consecutive patients. They were aged 35 to 84 years (median 64 years); 12 premenopausal and 60 postmenopausal. Pathological details are given in table 2. Before surgery, each patient was screened for metastatic disease by clinical examination, chest radiography, liver function tests (plasma alkaline phosphatase, $\gamma$ glutamyl transferase) and liver ultrasound. All were free from metastases. Depending on tumour size and location, surgery comprised tumourectomy, quadrantectomy, or mastectomy, plus axillary lymph node dissection. There was a high prevalence of small tumours without lymph node involvement and frequent positive hormone receptor status suggesting a favourable prognosis (table 2).

\section{MARROW SPECIMENS FROM BREAST CANCER} PATIENTS

A mean volume of $6 \mathrm{ml}$ of bone marrow pooled from two aspirations per site (sternum, right and left anterior iliac crests) was obtained in heparin-lithium anticoagulant. Bone marrow cells were separated on a Ficoll-Hypaque density gradient by centrifugation at $250 \times g$ for 20 minutes. The mononuclear layer was extracted and washed twice in RPMI 1640 medium. The
Table 2 Pathological data on 72 operable breast cancer patients at initial diagnosis

\begin{tabular}{|c|c|c|}
\hline Parameters & No patients & $\%$ patients \\
\hline \multicolumn{3}{|l|}{ Tumour type } \\
\hline Ductal & 54 & 75 \\
\hline Lobular & 10 & 13.8 \\
\hline Mixed & 4 & 5.6 \\
\hline Other & 4 & 5.6 \\
\hline \multicolumn{3}{|l|}{ Tumour size } \\
\hline $\mathrm{T} 1$ & 47 & 65.3 \\
\hline $\mathrm{T} 2$ & 19 & 26.4 \\
\hline T3 & 5 & 6.9 \\
\hline Unknown & 1 & 1.4 \\
\hline \multicolumn{3}{|l|}{ Tumour stage* } \\
\hline I & 33 & 45.9 \\
\hline IIA & 29 & 40.2 \\
\hline IIB & 9 & 12.5 \\
\hline Unknown & 1 & 1.4 \\
\hline \multicolumn{3}{|l|}{ Tumour grade } \\
\hline I & 20 & 27.8 \\
\hline II & 26 & 36.1 \\
\hline III & 7 & 9.7 \\
\hline Unclassifiable & 19 & 26.4 \\
\hline \multicolumn{3}{|c|}{ Oestrogen receptor status } \\
\hline Positive & 59 & 82 \\
\hline Negative & 8 & 11 \\
\hline Not tested & 5 & 7 \\
\hline \multicolumn{3}{|c|}{ Progesterone receptor status } \\
\hline Positive & 45 & 62.5 \\
\hline Negative & 22 & 30.5 \\
\hline Not tested & 5 & 7 \\
\hline \multicolumn{3}{|c|}{ Lymph node involvement } \\
\hline None & 49 & 68.1 \\
\hline $1-3$ & 17 & 23.6 \\
\hline 4 and more & 6 & 8.3 \\
\hline
\end{tabular}

Cut-off for oestrogen and progesterone receptors: $10 \mathrm{fmol} / \mathrm{mg}$ protein.

^UICC classification; $\ddagger$ Scarff-Bloom-Richardson.

final suspension was adjusted to $3 \times 10^{6}$ cells $/ \mathrm{ml}$ and cytospun onto 30 slides. Two slides were stained by the MGG technique for cytological examination; the other slides were air dried at room temperature for 24 to 48 hours, then stored at $-20^{\circ} \mathrm{C}$ or fixed and treated for immunocytochemistry (three slides for each antibody). Bone marrow biopsy was not performed in this study.

POSITIVE CONTROL SPECIMENS

Sixteen samples containing breast tumour cells were studied: seven ascites, four pleural effusions, three bone marrow specimens, one nodal aspirate, and the CAL 51 breast cancer cell line. ${ }^{16}$ 
Table 3 Monoclonal antibody characteristics

\begin{tabular}{lllll}
\hline Marker investigated & Antibody & Dilution used & Isotype & Supplier \\
\hline Cytokeratins $^{26} 10111819$ & $\mathrm{KL}_{1}$ & $1 / 100$ & IgG1 & Immunotech \\
Epithelial membrane antigen & $\mathrm{EMA}$ & Pure & IgG $_{2 \mathrm{a}}$ & Dako \\
& $\mathrm{HMFG}$ & $1 / 100$ & IgG1 & Immunotech \\
Polymorphic epithelial mucin & $\mathrm{CA} 15.3$ & Pure & IgG1 & Cis-Bio \\
\hline
\end{tabular}

Table 4 Positive controls: ratio of positive specimens with each $M o A b$

\begin{tabular}{llllll}
\hline & $K L_{I}$ & $H M F G_{2}$ & $E M A$ & CA 15.3 & No specimens \\
\hline & + & + & + & + & 7 \\
& + & + & + & Not tested & 1 \\
& + & + & - & + & 5 \\
& + & + & - & - & 1 \\
\multirow{3}{*}{ Positive cases } & + & + & - & Not tested & 1 \\
& + & - & - & - & 1 \\
& $16 / 16$ & $15 / 16$ & $8 / 16$ & $12 / 14$ tested & 16 \\
\hline
\end{tabular}

NEGATIVE CONTROL SPECIMENS

Marrow samples from 22 patients without epithelial tumour and without bone marrow involvement were obtained. Nine non-Hodgkin lymphomas, two Hodgkin's disease, two acute myeloid leukaemia in complete remission, one refractory anaemia with excess of blasts in remission, one idiopathic thrombopaenic purpura, three neuroblastomas, one rhabdomyosarcoma, one Ewing tumour, one congenital dyserythropoiesis, and one $\alpha$ thalassaemia (trait form).

MONOCLONAL ANTIBODIES (MOAB)

A panel of four murine antiepithelial MoAb (table 3) known to react with most human primary breast cancers was tested ${ }^{17}: \mathrm{KL}_{1}{ }^{18}$ EMA, ${ }^{19} \mathrm{HMFG}_{2},{ }^{20}$ and CA 15-3 (DF3). ${ }^{21}$ For each MoAb the optimum dilution was tested on epithelial cells and haematopoietic cells to avoid a positive background.

IMMUNOCYTOCHEMICAL STAINING PROCEDURE

The APAAP technique was used. ${ }^{14}$ In brief, after fixation of the slides for five minutes in acetone, the primary $\mathrm{MoAb}$ was incubated for 30 minutes at room temperature in a humid chamber. The second linking antibody, rabbit antimouse immunoglobulin 1:25 (Dako Trappes, France), was incubated in the same conditions. The cell preparations were washed twice with phosphate buffered saline (PBS). A mouse APAAP complex (Dako) of alkaline phosphatase and antialkaline phosphatase MoAb diluted to 1:25 in PBS was then applied for 30 minutes. Primary MoAb binding was visualised by hydrolysing a phosphate naphthol ester substrate in solution with levamisole to block endogenous phosphatase activity; the released phenols, coupled with brentamine fast red chromagen, give an insoluble red stain. The cells were counterstained with Mayer's haematoxylin for 30 seconds and mounted in glycerol-gelatin. The reaction was performed in triplicate for each antibody.

Table 5 Negative controls: results on 22 marrow samples

\begin{tabular}{lllll}
\hline Cases & $K L_{1}$ & $H M F G_{2}$ & $E M A$ & CA 15.3 \\
\hline Negative & 16 & 17 & 18 & Difficult \\
With positive plasmocytes & 4 & 3 & 2 & to \\
With positive stromal cells & 3 (1 with plasmocytes) & 2 & 2 & interpret \\
With positive myeloid stem cells & 0 & 0 & 0 & 22 \\
\hline
\end{tabular}

CONTROL OF THE SPECIFICITY

Negative controls were performed for each experiment and each antibody by replacing the primary MoAb with PBS or irrelevant mouse $\mathrm{IgG}_{1}$ or $\mathrm{IgG}_{2}$ immunoglobulin corresponding to the MoAb isotypes tested (table 3). The CAL 51 breast cancer cell line ${ }^{16}$ or a metastatic breast cancer effusion (pleural or peritoneal) was used as a positive control for each series of slides.

\section{SENSITIVITY OF THE TEST SYSTEM}

A sample of normal human bone marrow obtained on heparin-lithium was contaminated by CAL 51 breast cancer cells and maintained since October 1985 in Dulbecco's modified minimum essential medium with Earle's salts (DHEM, Boehringer, France SA) supplemented with $10 \%$ fetal calf serum. ${ }^{16}$ The cancer cells in culture were separated by trypsinisation and washed in RPMI medium. They were introduced in decreasing concentrations as aliquots of $5 \times 10^{6}$ normal marrow cells per $5000,500,50,5,0.5,0.05$ cancer cells to obtain final concentrations of $1: 10^{3}, 1: 10^{4}$, $1: 10^{5}, 1: 10^{6}, 1: 10^{7}$, and $1: 10^{8}$ normal marrow cells. Each cell preparation was treated in the same manner as the marrow samples from the breast cancer patients. $\mathrm{KL}_{1}$ was used to test the sensitivity of the method because it was strongly positive on CAL 51 breast cancer cells and it is known to be the most specific and the most constantly positive MoAb for mammary adenocarcinoma cells. $^{2}$

\section{Results}

SENSITIVITY OF THE METHOD

The test system, consisting of normal human bone marrow contaminated with the CAL 51 breast cancer cell line, ${ }^{16}$ revealed that the technique was sensitive enough to detect at least one cancer cell in $10^{6}$ haematopoietic cells.

\section{CONTROL DATA}

Positive controls

As shown in table $4, \mathrm{KL}_{1}$ was positive in all 16 specimens, $\mathrm{HMFG}_{2}$ in 15 of 16 and EMA in 8 of 16 specimens. CA 15-3, tested in 14 specimens, was strongly positive in 12 cases.

\section{Negative control specimens}

As shown in table $5, \mathrm{KL}_{1}, \mathrm{EMA}$, and $\mathrm{HMFG}_{2}$ non-specifically labelled only some well recognisable plasmocytes and stromal cells. CA 15-3 was positive in the myeloid stem cells; therefore, because of its non-specificity in this study it was given up, although it was an excellent marker for mammary cells.

\section{PATIENTS}

No evidence of marrow tumour cells was found in any of the 72 patients. Nevertheless, a granular but particularly intense positivity similar to that of tumoral cells was observed in nine of the 72 patients $(12 \%)$ with the panel of three MoAb as shown in figure 1 . Attention to their morphological characteristics and their frequency on cytospins permitted detection of these cells by careful examination of MGG stained slides (figs 2 and 3 ). Six of these nine 


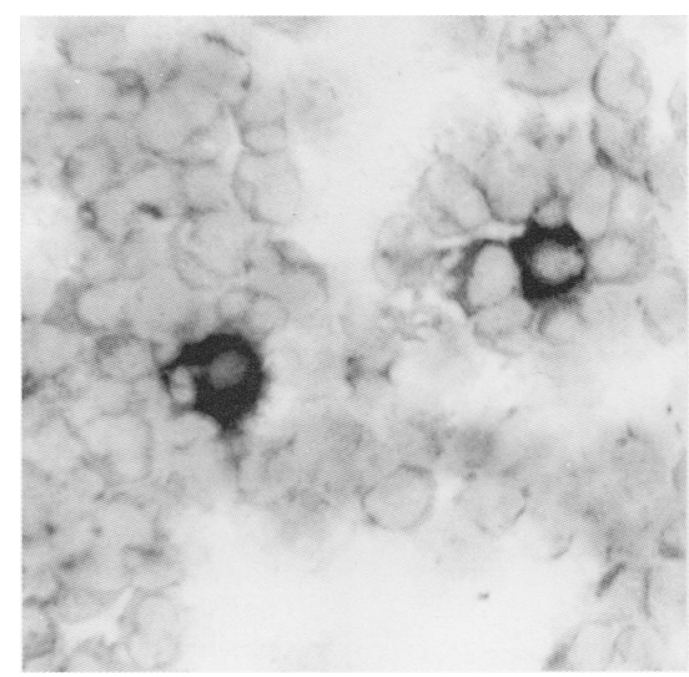

Figure 1 Two cells strongly positive with $\mathrm{HMFG}_{2}$ and $A P A A P$ in one patient (original magnification $\times 500$ ).

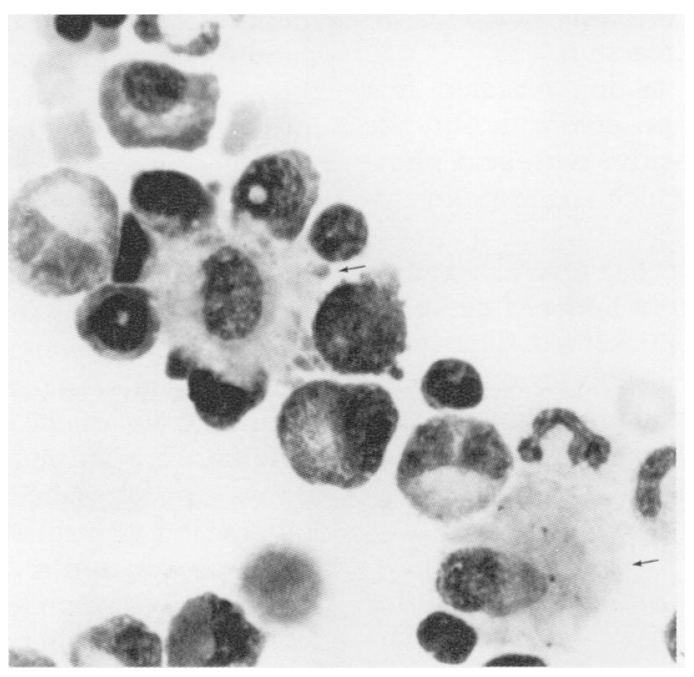

Figure 2 May-Grünwald-Giemsa stained stromal cells corresponding to cells similar to those of figure 1 (original magnification $\times 1000$ ).

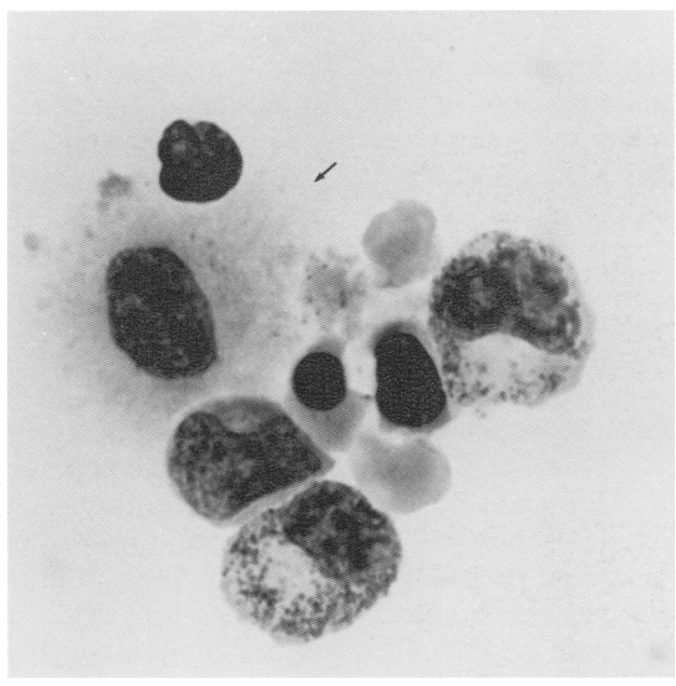

Figure 3 May-Grünwald-Giemsa stained stromal cell in the same patient as figure 2 (original magnification $\times 1000$ ).

patients were node negative and three were node positive; histologically, five patients were stage I, and four had stage II disease; four were grade I, three grade II, and two non-classified.

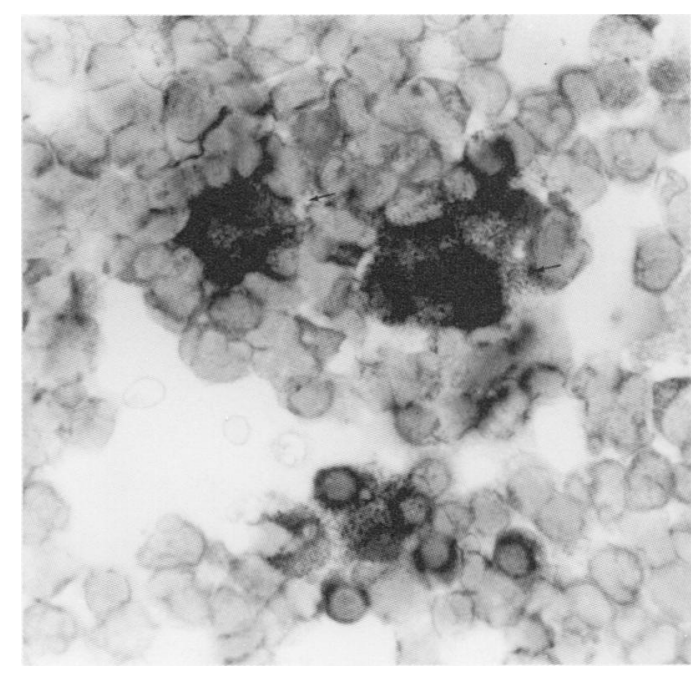

Figure 4 May-Grünwald-Giemsa stained cells positive without the primary antibody (original magnification $\times 500$ ).

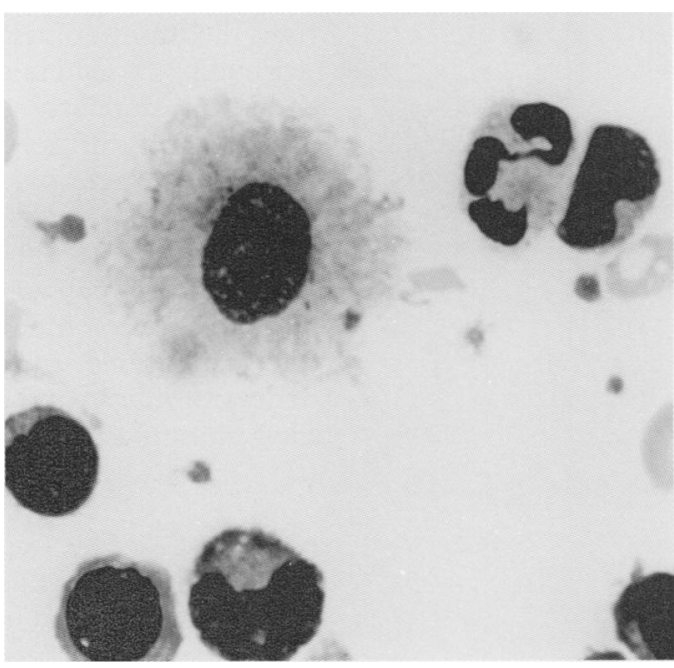

Figure 5 Marrow stromal cell in a negative control (May-Grünwald-Giemsa) (original magnification $\times 1000$ ).

These cells were obviously not tumoral, but rather medullary stromal cells (probably histiocytes) for three reasons:

(1) Their cytological appearance: in MGG stained slides these cells look like histiocytes with their oval often irregular nucleus, thin chromatin forming a homogeneous network, rare small nucleoli, abundant cytoplasm with irregular outlines giving them a sea urchin appearance on cytospins, often submerged in the centre of a nidus of cells (figs 2, and 3), usually erythroblasts. No evidence of malignancy were found and they were always isolated.

(2) Non-specificity of immunological labelling: these cells remained positive even when the primary antibody was replaced by the $\operatorname{IgG}_{1}$ or $\operatorname{IgG}_{2}$ isotype (fig 4 ).

(3) The same type of cells can be observed in all marrow cytospins stained with MGG even from normal controls (fig 5), but in these cases any immunological reactivity was not as intense as in marrow from some cancer patients.

To test the hypothesis that $\mathrm{Fc}$ receptors might be responsible for this non-specific fixation, slides were pretreated with aggregated human 


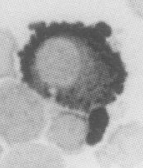

Figure 6 Immunolabelled plasmocyte (original magnification $\times 500$ ).

immunoglobulins; however, this failed to inhibit the immunological reaction.

Finally, cytochemical testing revealed that these cells were strongly positive with butyrate esterase and diffusely positive with acid phosphatase, characteristics which suggest a histiocyte origin.

In addition to these cells, several strongly labelled plasmocytes with a laky red cytoplasmic stain were sometimes observed. They were easily identified by their eccentric nucleus, dense chromatin and abundant cytoplasm, and their archoplasm was still visible in some cases (fig 6).

FOLLOW UP

During short term follow up (21 to 38 months, median 29 months), six of $72(8.3 \%)$ patients had developed a metastatic disease, one of these six had false positive marrow cells (T2, node-positive, grade III).

\section{Discussion}

In this study, marrow cells from nine of 72 (12\%) M0 breast cancer patients labelled with three antiepithelial antibodies were shown to be of non-tumoral nature. CA 15.3 which labelled myeloid stem cells was given up as it cannot be recommended for bone marrow investigations. Our results differ from those of most authors ${ }^{135781322-24}$ but agree with those of five other investigators (table 1). ${ }^{2561112}$ Certain cells, whose immunological labelling was similar to that of cancer cells, were labelled non-specifically. These cells corresponded to stromal cells, which are also found in normal marrow and fix the linking antibody in the absence of primary antibody, or to plasmocytes, which have a characteristic morphology and are known to react with EMA and $\mathrm{HMFG}_{2}{ }^{20}{ }^{25}$ as well as with cytokeratin. ${ }^{21}$ These cells cannot correspond to a skin contamination while they are non-specifically labelled.

Meticulous comparison of immunologicallytreated cytospins and MGG stained cytospins was required to identify these stromal cells. Such comparisons of immunological and cytological results remain mandatory. Although the APAAP technique is known to be superior to immunofluorescence for preservation of cellular morphology, it alters cell structures sufficiently so that it becomes difficult, even for experienced cytologists, to affirm the epithelial and tumoral nature of isolated immunologically labelled cells. Such comparisons are not always mentioned in the literature, and few photographs have been published. In addition, controls of specificity with replacement of the primary antibody by its IgG isotype, are not performed routinely, even though they are required (table 1). Finally, while the nonspecificity of the antibodies used separately requires a panel or cocktail of MoAb, ${ }^{5}$ several publications report use of only a single antibody (table 1).

The sensitivity of our technique is not responsible for the differences between our findings and published results: we detected one cancer cell in $10^{6}$ marrow cells with the APAAP technique considered superior to other methods, ${ }^{1522} 23$ and we used the optimum number of aspirations: six aspirations from three sites determined by several investigators. ${ }^{1513}$ The high prevalence of favourable prognostic factors in our patients could in part explain our negative results as only six of 72 patients had more than three involved lymph nodes, none of them had any labelled cells. The short term follow up does not support any conclusion.

Two points remain unclear. First, the stromal cells of $12 \%$ of the breast cancer patients were strongly labelled yet they were always weakly labelled in normal marrow. Patient and control samples were assessed in the same way and at the same time and slides were reviewed when necessary. One can concur with Rabkin et al that reactivity with EMA may be a marker of histiocyte activation. ${ }^{26}$ Nevertheless this hypothesis requires other proofs of histiocytic activation in breast cancer patients. In the present study, these positive stromal cells were found with the three MoAb both in stage I and stage II disease, and in node-positive as well as negative patients. Second, while plasmocytes were relatively frequent on the marrow cytospins from breast cancer patients, only a small number were immunologically labelled by the three antibodies and always in intense manner.

While the possibility of marrow tumour cells in breast cancer patients classed $\mathrm{MO}$ at the time of diagnosis cannot be ruled out, we suggest that literature results can be overestimated owing to antibody non-specificity and the difficulties encountered in interpretation of immunoreactive non-tumoral cells versus tumoral cells in the absence of any characteristic clumps. Proof of the tumoral nature of isolated cells is often inconclusive, and although immunocytochemistry and immunofluorescence are reference techniques for the detection of residual disease by cytopheresis prior to autotransplantation, ${ }^{27}{ }^{28}$ they may be suitable methods for marrow tumour cell detection only if more specific MoAb are found. It seems to be the case for cytokeratine 19 which does not label any myeloid cells. Molecular biology techniques may be promising, faster, and 
probably more reliable and the two techniques should be compared. ${ }^{29-31}$ Confirmation of the presence of marrow tumour cells in nodenegative operable breast cancer patients, associated with demonstration of their clonogenic capacity, is indispensable if this criterion is to serve as the basis for adjuvant therapy or become a major prognostic factor.

This work was supported by La Ligue Nationale Française This work was supported by La Ligue Nationale Française thank N Rameau for translation of the manuscript.

1 Diel IJ, Kaufmann M, Goerner R, Costa SD, Kaul S, Bastert G. Detection of tumor cells in bone marrow of patients with primary breast cancer: a prognostic factor for distant primary breast cancer: a prognostic fact

2 Mathieu MC, Friedman S, Bosq J Caillou B, Spielmann M, Travagli JP, et al. Immunocytochemical staining of bone marrow biopsies for detection of occult metastasis in breast cancer. Breast Cancer Res 1990;15:21-6.

3 Mansi JL, Easton D, Berger U, Gazet JC, Ford HT, Dearnaley $\mathrm{D}$, et al. Bone marrow micrometastases in primary
breast cancer: Prognostic significance after 6 years' follow up. Eur $\mathcal{f}$ Cancer 1991;27:1552-5.

4 Pecorini F, Veneziano M, Framarino Dei Malatesta ML, Passarello A, Trapani E, et al. Considerations on the prognostic significance of bone marrow micrometastases in breast cancer. Eur $\mathcal{F}$ Gynec Oncol 1993;14:501-5.

5 Harbeck N, Unch M, Pache L, Eiermann W. Tumour detection in the bone marrow of breast cancer patients at detection in the bone marrow of breast cancer patients at
primary therapy: results of a 3-year median follow-up. $B r f$ primary therapy: results

6 Sloane JP, Ormerod MG, Imrie SF, Coombes RC. The use of antisera to epithelial membrane antigen in detecting micrometastases in histological sections. Br $\mathcal{F}$ Cancer 1980; 2:392-8.

7 Cote RJ, Rosen PP, Lesser ML, Old LJ, Osborne MP. Prediction of early relapse in patients with operable breast cancer by detection of occult bone marrow micrometastases. F Clin Oncol 1991;10:1749-56.

8 Osborne MP, Wong GY, Gonzales A, Potter C, Vlamis V, Cote RJ. Bone marrow micrometastases in breast cancer: the effect of systemic tumor cell burden on early relapse [abstract]. Proc Am Soc Clin Oncol 1993;12:75.

9 Merkle E, Henke, Bähr I, Bühner M, Lang N. Tumor cell detection in bone marrow of primary breast cancer patient [abstract]. Eur $\mathcal{f}$ Cancer 1994;30(suppl 1):S22.

10 Diel IJ, Kaufmann M, Solomayer EF, Costa SD, GrhberHoffmann B, Kaul S, et al. Micrometastatic tumor cells in bone marrow versus nodal status in breast cancer. Impact on prognosis in patients with primary breast cancer [abstract]. Proc Am Soc Clin Oncol 1995;14:110.

11 Courtemanche DJ, Worth AJ, Coupland RW, Rowell JL Mac Farlane JK. Monoclonal antibody LICR-LON-M8 does not predict the outcome of operable breast cancer. Can f Surg 1991;34:21-6.

12 Giai M, Natoli C, Sismondi P, Biglia N, Lesti G, Mulieri M, et al. Bone marrow micrometastases detected by a
monoclonal antibody in patients with breast cancer. monoclonal antibody in patient

13 Coombes RC, Berger U, Mansi J, Redding H, Powles TJ, Neville AM. Prognostic significance of micrometastases in bone marrow in patients with primary breast cancer. NCI Monogr 1986:51-3.

14 Cordell JL, Falini B, Erber MW, Ghosh AK, Abdulaziz Z, Mac Donalds $S$, et al. Immunoenzymatic labeling of monoclonal antibodies using complex of alkaline phosphatase antialkaline phosphatase (APAAP complexes). 7 Histochem Cytochem 1984;32:219-29.

15 Molino A, Colombatti M, Bonetti F, Zardini M, Pasini F, Perini A, et al. A comparative analysis of three different techniques for the detection of breast cancer cells in bone marrow. Cancer 1991;67:1033-6.

16 Gioanni J, Lefrançois D, Zanghellini E. Establishment and characterisation of a new tumorigenic cell line with a normal karyotype derived from a human breast adenocarcinoma. Br f Cancer 1990;62:8-13.

17 Thor A, Viglione MJ, Ohuchi N, Simpson J, Steis R, Cousar $\mathrm{J}$, et al. Comparison of monoclonal antibodies for the detection of occult breast carcinoma metastases in bone marrow. Breast Cancer Res 1988;11:133-45.

18 Viac J, Reano A, Brochier J, Staquet MJ, Thivolet J. Reactivity pattern of a monoclonal antikeratin antibody (KLI). $\mathcal{f}$ Invest Dermatol 1980;81:351-4.

19 Pinkus GS, Kurtin PJ. Epithelial membrane antigen, a diagnostic discriminant in surgical pathology: Immunohistochemical profile in epithelial mesenchymal and hematopoichemical profile in epithelial mesenchymal and hematopoietic neoplasms using paraffin sections and
antibodies. Human Pathol 1985;16:929-40.

20 Taylor-Papadimitrio J, Peterson JA, Arklie J, Burchell J, Ceriani RL, Bodmer WF. Monoclonal antibodies to epithelium specific components of the human milk fat globule membrane: production and reaction with cells in culture. Int $\mathcal{F}$ Cancer 1980;28:17-21.

21 Kufe DW, Inghirami G, Abe M, Hayes D, Justiwheeler H, Schlom J. Differential reactivity of a novel monoclonal antibody (DF3) with human malignant versus benign antibody (DF3) with human malignant

22 Porro G, Menard S, Tagliabue E, Orefice S, Salvadori B, Squicciarini $\mathrm{P}$, et al. Monoclonal antibody detection of carcinoma cells in bone marrow biopsy specimens from breast cancer patients. Cancer 1988;61:2407-11.

23 Ellis G, Ferguson M, Yamanaka E, Livingston RB, Gown AM. Monoclonal antibodies for detection of occult carcinoma cells in bone marrow of breast cancer patients. Cancer 1989;63:2509-14.

24 Menard S, Squicciarini P, Luigni A, Sacchini V, Rovini D, Tagliabue E, et al. Immunodectection of bone marrow micrometastases in breast carcinoma patients and its correlation with primary tumour prognostic features. $\mathrm{Br} \mathcal{F} \mathrm{Can}$ cer 1994;69:1126-9.

25 Delsol G, Stein H, Pulford KAF, Gatter KC, Erber WN, Zinne $\mathrm{K}$, et al. Human lymphoid cells express epithelial membrane antigen. Implications for diagnosis of human neoplasms. Lancet 1984;ii:1124-9.

26 Rabkin MS, Kjeldsberg CR. Epithelial membrane antigen staining patterns of histiocytic lesions. Arch Pathol Lab Med 1987;111:337-8.

27 Shpall EJ, Jones RB, Bearman SL Franklin WA, Archer PG, Curiel T, et al. Transplantation of enriched CD34-positive autologous marrow into breast cancer patients following high-dose chemotherapy: influence of CD34-positive peripheral blood progenitors and growth factors on engrafment. F Clin Oncol 1994;12:28-36.

28 Ross AA, Cooper BW, Lazarus HM, Mackay W, Moss TJ, Ciobanu N, et al. Detection of viability of $T$ cells in peripheral blood stem cell collections from breast cancer patients using immunochemical and clonogenic assay techniques. Blood 1993;82:2605-10.

29 Datta YH, Adams PT, Drobyski WR, Ethier SP, Terry VH, Roth MS. Sensitive detection of occult breast cancer by the reverse-transcriptase polymerase chain reaction. $\mathrm{f}$ Clin Oncol 1994;12:475-82.

30 Schoenfeld A, Kruger KH, Gomm J, Sinnett HD, Gozet JC, Sacks $\mathrm{N}$, et al. The detection of micrometastases in the lymph nodes peripheral blood and bone marrow of patients lymph nodes peripheral blood and bone marrow of patients with breast cancer using immunohistochemistry and
polymerase chain reaction. In: Calvo $F$, Crépin $M$, Magdepolymerase chain reaction. In: Calvo $\mathrm{F}$, Crepin $\mathrm{M}$, Magde-
lenat $\mathrm{H}$, eds. Breast cancer. Advances in biology and therapeulenat H, eds. Breast cancer. Advances in biology and thera
tics. London: John Libbey Eurotext 1996:289-302.

31 Fields KK, Elfenbein GJ, Trudeau WL, Perkins JB, Janssen WE, Moscinski LC. Clinical significance of bone marrow metastases as detected using the polymerase chain reaction in patients with breast cancer undergoing high-dose chemotherapy and autologous bone marrow transplantation. F Clin Oncol 1996;14:1868-76. 